\title{
An efficient synthesis of indolo[2,3-b]quinoline guanidine derivatives with their in vitro and in vivo study
}

\author{
Katarzyna Sidoryk $\mathbb{D}^{1} \cdot$ Marta Świtalska $^{2} \cdot$ Piotr Rózga $^{3} \cdot$ Joanna Wietrzyk $^{2}$ • \\ Iwona Bujak $^{1} \cdot$ Bartłomiej Żerek $^{3} \cdot$ Lukasz Kaczmarek $^{1} \cdot$ Marcin Cybulski $^{1}$
}

Received: 13 June 2017 / Accepted: 5 August 2017 / Published online: 5 September 2017

(C) The Author(s) 2017. This article is an open access publication

\begin{abstract}
An optimization of the guanidylation process by verifying the efficacy of common guanylation reagents in order to obtain the guanidine derivatives of indolo[2,3-b] quinoline has been performed. As a result, a high-yield procedure using $N, N^{\prime}$-di-Boc- $N^{\prime \prime}$-triflylguanidine was applied to synthesize the guanidine derivative of indolo[2,3-b] quinoline $\mathbf{1}$ in a gram scale for specific in vitro and in vivo biological research. Extensive studies on the antiproliferative activity against eight human tumor cell lines were completed. Compound $\mathbf{1}$ revealed the highest activity against A549 lung adenocarcinoma and MCF7 breast cancer cell lines. Thus, $\mathbf{1}$ was evaluated for the in vivo anticancer activity against 4T1 mammary gland carcinoma and KLN205 murine lung carcinoma in mouse models. The anticancer effect was observed in the KLN205 model with a $37 \%$ tumor growth inhibition at the $20 \mathrm{mg} / \mathrm{kg}$ dose. This anticancer activity of $\mathbf{1}$ was comparable to that of cyclophosphamide which inhibited murine lung tumor growth in the range of $27-43 \%$ at the dose of $100 \mathrm{mg} / \mathrm{kg}$. The biochemistry research after $\mathbf{1}$ admission, including measurements of blood parameters like alanine aminotransferase, aspartate aminotransferase, lactate dehydrogenase, and urea and creatinine, were also performed.
\end{abstract}

Dr. Krzysztof Bańkowski is deceased. This paper is dedicated to his memory.

Katarzyna Sidoryk

k.sidoryk@ifarm.eu

1 Pharmaceutical Research Institute, 8 Rydygiera St., 01-793 Warszawa, Poland

2 Institute of Immunology and Experimental Therapy, Polish Academy of Sciences, 12 Weigla St., 53-114 Wrocław, Poland

3 Adamed Group, Oncology Group, Pieńków 149, 05-152 Czosnów, Poland
Keywords Guanidine group · Indolo[2,3-b]quinoline · Guanidylation $\cdot$ Antiproliferative activity $\cdot$ Anticancer activity

\section{Introduction}

The guanidine group widely exists in various natural products and pharmaceutically active compounds (Yamamoto et al. 1991; Heys et al. 2000; Snider and Shi 1994; Coffey et al. 2000; Yuan and Williams 1997; Orner and Hamilton 2001). Due to its strong basic properties $\left(\mathrm{pK}_{\mathrm{a}}\right.$ 12.5), it actively interacts with the phosphate residues of the minor groove of the DNA helix (Králová et al. 2003). Besides stabilizing the drug-DNA complex, the guanidine group may also improve the delivery of the substances inside cancer cells by increasing their hydrophilic properties and water solubility, while simultaneously decreasing their toxicity (Hau et al. 2002; Liu et al. 2006; Pantos et al. 2008; Chari 2008). Our previous studies have demonstrated that the attachment of a guanidine or guanyl-amino acid chain to the indolo[2,3-b]quinoline core significantly improved its selectivity by increasing the cytotoxic activity against some cancer cell lines, but not against normal cells (Fig. 1) (Sidoryk et al. 2015). The cytotoxic activity of the guanidine-DiMIQ derivative (1) was notably higher against cancer cell lines than against normal cells (mice fibroblasts BALB/3T3) (Sidoryk et al. 2015).

Such extremely high selectivity has rarely been observed for standard anticancer drugs. For example, the cytotoxicity of Doxorubicin, widely used in cancer treatment against both cancer and normal cell lines, is comparable. Moreover, the guanidine derivatives of DiMIQ (1 and 3) are very 
Fig. 1 The structures of indolo [2,3-b]quinoline guanidine derivatives, $\mathrm{R}$ - amino acid



effective inducers of apoptosis. It follows that the extreme selectivity of the guanidine-DiMIQ conjugate may result from a new, unique molecular mechanism of action. Also, an important and promising feature of these compounds is the absence of hemolysis (Sidoryk et al. 2015).

Thus $\mathbf{1}$ and $\mathbf{3}$ derivatives have been selected for the extensive evaluation of their in vitro antiproliferative activity against several types of cancer cell lines (A549, NCI-H460, HCT116, HT-29, ACHN, HepG2, MCF-7, and A431) and normal cells (human fibroblasts CCD11Lu). In addition, the impact of the compounds on tumor growth was to be investigated in an in vivo mouse model. During our previous studies, it had been experimentally verified that the guanidylation by $N, N^{\prime}$-Bis(tert-butyloxycarbonyl)- $S$-methylisothiourea in a two-step synthetic sequence allows to obtain samples of guanidine derivatives for biological screening in average yields. However, this approach seemed to be problematic in the upscaling process because of the release of mephitic methyl mercaptan. For that reason, it was necessary to find a new, effective, and reproducible synthetic method which would lead us to obtain $\mathbf{1}$ and $\mathbf{3}$ guanidine analogs in a gram scale for pre-clinical tests.

In this paper, we describe the optimization process, a new, improved synthetic strategy for the production of guanidine analogs, and biological in vitro and in vivo characteristics of compounds $\mathbf{1}$ and $\mathbf{3}$.

\section{Matarials and methods}

\section{Chemistry}

\section{General}

The ${ }^{1} \mathrm{H}$ and ${ }^{13} \mathrm{C}$ nuclear magnetic resonance (NMR) spectra of all compounds studied were measured in $\mathrm{CDCl}_{3}$, dimethyl sulfoxide (DMSO)- $\mathrm{D}_{6}$, or $\mathrm{D}_{2} \mathrm{O}$ using Varian-NMRvnmrs500, Varian-NMR-vnmrs600, and Varian Gemini 200 spectrometers at the temperature of 298 K. Standard experimental conditions and standard Varian programs were used. To assign the structures under consideration, the following 1D and 2D experiments were employed: the 1D selective NOESY and 2D gradient-selected COSY, ${ }^{1} \mathrm{H}_{-}{ }^{13} \mathrm{C}$ heteronuclear single quantum correlation, and ${ }^{1} \mathrm{H}_{-}{ }^{13} \mathrm{C}$ Heteronuclear Multiple Bond Correlation. The ${ }^{1} \mathrm{H}$ and ${ }^{13} \mathrm{C}$

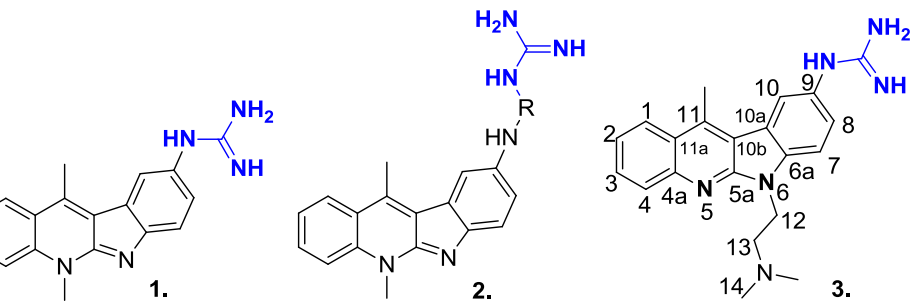

NMR chemical shifts relate to the tetramethylsilane (for compounds dissolved in $\mathrm{CDCl}_{3}$ or DMSO-D 6 ) and DSS (for compounds dissolved in $\mathrm{D}_{2} \mathrm{O}$ ). The concentration of all solutions used for the measurements was about 10-20 mg of the compounds in $0.6-0.8 \mathrm{~cm}^{3}$ of the solvent.

The electrospray ionization-mass spectrometry (ESI-MS) spectra were recorded on a PE Biosystems Mariner mass spectrometer. The progress of the reaction was monitored by thin layer chromatography (TLC) using Merck DCAlufolien Kieselgel $60 \mathrm{~F}_{254}$. The chemicals and solvents were purchased from Fluka Company. Column chromatography was performed on Merck silica gel 60 (230-400 mesh).

The chromatographic analysis was performed using a Shimadzu high performance liquid chromatography (HPLC) system (Shimadzu Corporation, Japan) consisting of a Shimadzu LC-20AB pump, Shimadzu SIL-20AC autosampler, Shimadzu CTO-10AS VP column oven, and Shimadzu SPD-M20A photodiode array detector. The separation of the analyte from potential impurities was achieved using a Kromasil C8 column $(150 \times 4.6 \mathrm{~mm}, 3.5$ $\mu \mathrm{m}$, Kromasil) placed in a thermostated column heater at 30 ${ }^{\circ} \mathrm{C}$. The mobile phases consisting of A $(0.1 \%$ TFA in water $)$ and $\mathrm{B}(0.1 \%$ TFA in acetonitrile) were used with the gradient mode at the flow rate of $1 \mathrm{ml} / \mathrm{min}$. The samples were prepared at the concentration of about $0.2 \mathrm{mg} / \mathrm{ml}$ and they were dissolved in methanol (compound 5) and water (compound 1). The injection volume was $10 \mu \mathrm{l}$. Ultraviolet (UV) detection at $275 \mathrm{~nm}$ was used.

$\mathrm{N}$-[bis(tert-butyloxycarbonyl)guanyl]- $\mathrm{N}$-(5,11-dimethyl-5Hindolo[2,3-b]quinolin-9-yl)-amine (5) The amino component $4(1.5 \mathrm{~g}, 5.75 \mathrm{mM})$ was added to the solution of DIPEA $(2 \mathrm{ml}, 11.5 \mathrm{mM})$ and $N, N$-di-Boc- $N^{\prime \prime}$-triflylguanidine $(2.47$ $\mathrm{g}, 6.32 \mathrm{mM})$ in DCM $(40 \mathrm{ml})$. The mixture was stirred for 2 $\mathrm{h}$ at room temperature (TLC monitoring, chloroform: methanol 9:1 v/v). Next, the mixture was washed with $2 \mathrm{M}$ aqueous sodium bisulfate $(50 \mathrm{ml})$ and saturated sodium bicarbonate $(50 \mathrm{ml})$. Each aqueous layer was extracted with dichloromethane $(2 \times 30 \mathrm{ml})$. The combined organic phases were washed with brine $(40 \mathrm{ml})$, dried $\left(\mathrm{MgSO}_{4}\right)$, filtered, and concentrated under reduced pressure to afford crude compound 5. The compound was purified by column chromatography (chloroform: methanol 9:1 v/v) to afford a title compound $5(2.71 \mathrm{~g})$ as an orange solid with a good 
$94.61 \%$ yield. mp $210{ }^{\circ} \mathrm{C}$ (decomp.); ${ }^{1} \mathrm{H}$ NMR $\left(\mathrm{CDCl}_{3}, 600\right.$ $\mathrm{MHz}): \delta=8.78(1 \mathrm{H}, \mathrm{d}, J=1.84 \mathrm{~Hz}, \mathrm{H}-10), 8.24-8.21(1 \mathrm{H}$, m, H-1), 7.79-7.77 (2H, m, H-3, H-4), 7.65 (1H, d, $J=8.4$ $\mathrm{Hz}, \mathrm{H}-7), 7.61-7.26(2 \mathrm{H}, \mathrm{m}, \mathrm{H}-2, \mathrm{H}-8), 4.33(3 \mathrm{H}, \mathrm{s}$, $\left.\mathrm{Ar}-\mathrm{CH}_{3}\right), 3.12\left(3 \mathrm{H}, \mathrm{s}, \mathrm{Ar}-\mathrm{CH}_{3}\right), 1.57(9 \mathrm{H}, \mathrm{s}, t-\mathrm{Bu}), 1.52$ $(9 \mathrm{H}, \mathrm{s}, t-\mathrm{Bu}) ;{ }^{13} \mathrm{C} \mathrm{NMR}\left(\mathrm{CDCl}_{3}, 150 \mathrm{MHz}\right): \delta=163.5(\mathrm{C}$, $\left.\mathrm{HNC}(\mathrm{NH})_{2}\right), 154.2$ (C, 5a), 153.5 (C, NHCO-t-Bu), 153.3 (C, NCO-t-Bu), 150.0 (C, 6a), 141.5 (C, C-11), 136.5 (C, C-4a), 130.5 (CH, C-3), 129.5 (C, C-10a), 125.8 (CH, C-1), 124.6 (C, C-10b), 124.1(C, C-9), 123.2 (CH, C-8), 122.1 (CH, C-2), 121.5 (C, C-11a), 117.8 (CH, C-10), $116.6(\mathrm{CH}$, C-7), $114.7(\mathrm{CH}, \mathrm{C}-4), 83.5(\mathrm{C}, t-\mathrm{Bu}), 79.2\left(\mathrm{CH}_{3}, t\right.$-Bu), $33.5\left(\mathrm{CH}_{3}, \mathrm{Ar}-\mathrm{CH}_{3}\right), 28.2\left(\mathrm{CH}_{3}, t-\mathrm{Bu}\right), 28.1\left(\mathrm{CH}_{3}, t-\mathrm{Bu}\right)$, 15.1 $\left(\mathrm{CH}_{3}, \quad \mathrm{Ar}-\mathrm{CH}_{3}\right)$; HRESIMS $\mathrm{m} / \mathrm{z}: \quad 504.2611$ $\left(\mathrm{C}_{28} \mathrm{H}_{34} \mathrm{~N}_{5} \mathrm{O}_{4}\right)[\mathrm{M}+\mathrm{H}]^{+}$(calcd. 504.2605). The ${ }^{1} \mathrm{H}$ NMR and ${ }^{13} \mathrm{C}$ NMR data obtained were in good agreement with that reported in the literature (Sidoryk et al. 2015). HPLC: $94.82 \%$.

$\mathrm{N}$-guanyl- $\mathrm{N}$-(5,11-dimethyl-5H-indolo[2,3-b]qinolin-9-yl)amine dihydrochloride (1) Boc-derivative 5 (2.6 g, 5.16 $\mathrm{mM})$ was treated with TFA $(30 \mathrm{ml})$ and stirred for $24 \mathrm{~h}$ (TLC monitoring). The solution was evaporated to dryness, next $\mathrm{HCl} / \mathrm{CH}_{3} \mathrm{OH}$ was added and evaporated to dryness. This procedure was repeated three times. The residue was crystallized from ethyl acetate to afford a yellow solid; yield $1.64 \mathrm{~g}(84 \%)$; mp $260{ }^{\circ} \mathrm{C}$ (decomp.); ${ }^{1} \mathrm{H}$ NMR $\left(\mathrm{D}_{2} \mathrm{O}, 600\right.$ MHz): $\delta=8.16(1 \mathrm{H}, \mathrm{dd}, J=3.3 \mathrm{~Hz}, J=24 \mathrm{~Hz}, \mathrm{H}-1)$, 7.95-7.87 (1H, m, H-3), 7.86-7.84 (2H, m, H-4, H-10), 7.66-7.58 (1H, m, H-2), $7.48(1 \mathrm{H}, \mathrm{d}, J=23 \mathrm{~Hz}, \mathrm{H}-7), 7.39$ $(1 \mathrm{H}, \mathrm{dd}, J=5 \mathrm{~Hz}, J=23 \mathrm{~Hz}, \mathrm{H}-8), 3.92\left(3 \mathrm{H}, \mathrm{s}, \mathrm{Ar}-\mathrm{CH}_{3}\right)$, $2.76\left(3 \mathrm{H}, \mathrm{s}, \mathrm{Ar}-\mathrm{CH}_{3}\right) ;{ }^{13} \mathrm{C}$ NMR $\left(\mathrm{D}_{2} \mathrm{O}, 150 \mathrm{MHz}\right): \delta=$ $159.3\left(\mathrm{C}, \mathrm{HNC}(\mathrm{NH})_{2}\right), 152.7$ (C, C-11), 148.8 (C, C-5a), 140.8 (C, C-6a), 137.4 (C, C-4a), 136.7 (CH, C-3), 132.3 (C, C-9), 130.2 (CH, C-8), 129.1 (CH, C-1), 128.8 (CH, C2), 125.2 (C, C-11a), 124.1 (CH, C-10), 123.7 (C, C-10a), 120.9 (C, C-10b), 118.6 (CH, C-4), 116.3 (CH, C-7), 38.2 $\left(\mathrm{CH}_{3}, \mathrm{Ar}-\mathrm{CH}_{3}\right), 18.2\left(\mathrm{CH}_{3}, \mathrm{Ar}-\mathrm{CH}_{3}\right)$; The ${ }^{1} \mathrm{H}$ NMR and ${ }^{13} \mathrm{C}$ NMR data obtained were in good agreement with that reported in the literature (Sidoryk et al. 2015); HRESIMS $m / z: 304.1562\left(\mathrm{C}_{18} \mathrm{H}_{18} \mathrm{~N}_{5}\right)[\mathrm{M}+\mathrm{H}]^{+}$(calcd. 304.1560); anal. calcd. for $\mathrm{C}_{18} \mathrm{H}_{17} \mathrm{~N}_{5} \times 2 \mathrm{HCl}$ : C, 57.45; H, 5.09; N, $18.61 ; \mathrm{Cl}, 18.84$ found: $\mathrm{C}, 57.26 ; \mathrm{H}, 5.18 ; \mathrm{N}, 18.44 ; \mathrm{Cl}$, 18.67; HPLC: $97.38 \%$.

$N$-[bis(tert-butyloxycarbonyl)guanyl]- $N$-[6-(2-dimethylaminoethyl)-11-methyl-6H-indolo[2,3-b]quinolin-9-yl]-amine

(7) The amino component $6(200 \mathrm{mg}, 0.63 \mathrm{mM})$ was added to the solution of DIPEA $(0.33 \mathrm{ml}, 1.89 \mathrm{mM})$ and $N$, $N$-di-Boc- $N^{\prime \prime}$-triflylguanidine $(271.2 \mathrm{mg}, \quad 0.693 \mathrm{mM})$ in DCM $(10 \mathrm{ml})$. The mixture was stirred for $3 \mathrm{~h}$ at room temperature (TLC monitoring, chloroform:methanol 9:1 v/ v). Next, the mixture was washed with $2 \mathrm{M}$ aqueous sodium bisulfate $(15 \mathrm{ml})$ and saturated sodium bicarbonate $(15 \mathrm{ml})$. Each aqueous layer was extracted with dichloromethane $(2 \times 20 \mathrm{ml})$. The combined organic phases were washed with brine $(20 \mathrm{ml})$, dried $\left(\mathrm{MgSO}_{4}\right)$, filtered, and concentrated under reduced pressure to afford crude compound 7. The compound was purified by column chromatography (chloroform:methanol 9:1 v/v) to afford title compound 7 $(342 \mathrm{mg}$ ) as an orange solid with a good $96.9 \%$ yield; $\mathrm{mp}$ $220{ }^{\circ} \mathrm{C}$ (decomp.); ${ }^{1} \mathrm{H}$ NMR (DMSO-D $6,600 \mathrm{MHz}$ ): $\delta=$ $11.51(1 \mathrm{H}, \mathrm{s}, \mathrm{NH}), 10.12(1 \mathrm{H}, \mathrm{s}, \mathrm{NH}), 8.75(1 \mathrm{H}, \mathrm{br} \mathrm{s}, \mathrm{ArH})$, 8.39-8.38 (1H, m, ArH), 8.03-8.02 (1H, m, Ar-H), 7.81-7.76 (2H, m, ArH $), 7.73-7.71(1 \mathrm{H}, \mathrm{m}, \operatorname{ArH})$, 7.56-7.53 (1H, m, ArH), $4.86(2 \mathrm{H}, \mathrm{m}, \mathrm{H}-12), 3.58(2 \mathrm{H}, \mathrm{m}$, $\mathrm{H}-13), 3.18\left(3 \mathrm{H}, \mathrm{s}, \mathrm{Ar}-\mathrm{CH}_{3}\right), 2.92\left(6 \mathrm{H}, \mathrm{s}, \mathrm{N}\left(\mathrm{CH}_{3}\right)_{2}\right), 1.55$ $(9 \mathrm{H}, \mathrm{s}, t-\mathrm{Bu}), 1.40(9 \mathrm{H}, \mathrm{s}, t-\mathrm{Bu}) ;{ }^{13} \mathrm{C}$ NMR (DMSO-D 6 , $150 \mathrm{MHz}): \delta=162.7\left(\mathrm{C}, \mathrm{HNC}(\mathrm{NH})_{2}\right), 162.2(\mathrm{C}, \mathrm{C}-11)$, 153.5 (C, NHCO- $t$-Bu), 152.1(C, NCO- $t$-Bu), 151.6 (C, C5a), 145.6 (C, C-6a), 139.6 (CH, C-3), 138.4 (C, C-9), 129.9 (CH, C-8), 129.0 (CH, C-1), 127.5 (CH, C-2), 124.6 (C, C-11a), 123.9 (C, C-10a), 123.8 (CH, C-10), $123.0(\mathrm{CH}$, C-4), 119.1 (C, C-10b), 115.7 (CH, C-7), 83.3 (C, $t$-Bu), $78.5(\mathrm{C}, t-\mathrm{Bu}), 54.6\left(\mathrm{CH}_{2}, \mathrm{C}-13\right), 42.7\left(\mathrm{CH}_{2}, \mathrm{C}-12\right), 38.7$ $\left(\mathrm{CH}_{3}, \mathrm{C}-14\right), 36.5\left(\mathrm{CH}_{3}, \mathrm{C}-14\right), 30.7\left(\mathrm{CH}_{3}, t-\mathrm{Bu}\right), 27.8$ $\left(\mathrm{CH}_{3}, t-\mathrm{Bu}\right), 27.6\left(\mathrm{CH}_{3}, t-\mathrm{Bu}\right), 14.5\left(\mathrm{CH}_{3}, \mathrm{Ar}-\mathrm{CH}_{3}\right)$; The ${ }^{1} \mathrm{H}$ NMR and ${ }^{13} \mathrm{C}$ NMR data obtained were in good agreement with that reported in the literature (Sidoryk et al. 2015). HRESIMS $m / z$ : $561.3189\left(\mathrm{C}_{31} \mathrm{H}_{41} \mathrm{~N}_{6} \mathrm{O}_{4}\right)[\mathrm{M}+\mathrm{H}]^{+}$calc. 561.3179 .

$\mathrm{N}$-guanyl- $\mathrm{N}$-[6-(2-dimethylaminoethyl)-11-methyl-6Hindolo[2,3-b]quinolin-9-yl]-amine tetrahydrochloride (3) Product 7 (200 mg, $0.357 \mathrm{mM})$ was treated with TFA (10 $\mathrm{ml}$ ) and stirred for $24 \mathrm{~h}$ (TLC monitoring). The solution was evaporated to dryness, next $\mathrm{HCl} / \mathrm{CH}_{3} \mathrm{OH}$ was added and evaporated to dryness. The procedure was repeated three times. The residue was crystallized from ethyl acetate to afford a yellow solid; yield $140 \mathrm{mg}$ (77\%); mp $200-202{ }^{\circ} \mathrm{C}$; ${ }^{1} \mathrm{H}$ NMR $\left(\mathrm{D}_{2} \mathrm{O}, 500 \mathrm{MHz}\right): \delta=8.22-8.21(1 \mathrm{H}, \mathrm{m}, \mathrm{H}-1)$, $8.18(1 \mathrm{H}, \mathrm{d}, J=4 \mathrm{~Hz}, \mathrm{H}-10), 8.07-8.05(1 \mathrm{H}, \mathrm{m}, \mathrm{H}-4)$, 7.92-7.89 (1H, m, H-3), 7.76-7.71(2H, m, H-7, H-8), 7.65-7.62 (1H, m, H-2), $4.76(2 \mathrm{H}, \mathrm{m}, \mathrm{H}-12), 3.68(2 \mathrm{H}, \mathrm{m}$, $\mathrm{H}-13), 3.09\left(6 \mathrm{H}, \mathrm{s}, \mathrm{N}\left(\mathrm{CH}_{3}\right)_{2}\right), 2.96\left(3 \mathrm{H}, \mathrm{s}, \mathrm{Ar}-\mathrm{CH}_{3}\right) ;{ }^{13} \mathrm{C}$ $\mathrm{NMR}\left(\mathrm{D}_{2} \mathrm{O}, 125 \mathrm{MHz}\right): \delta=159.5\left(\mathrm{C}, \mathrm{NC}(\mathrm{NH})_{2}\right), 150.7(\mathrm{C}$, C-11), 149.6 (C, C-5a), 141.5 (C, C-6a), 140.7 (C, C-4a), 135.1 (CH, C-3), 131.8 (C, C-9), 129.9 (CH, C-8), 128.2 (C, C-2), 127.9 (C, C-1), 125.4 (C, C-11a), 124.9 (CH, C10), 124.3 (C, C-10a), 124.1 (CH, C-4), 119.6 (C, C-10b), $113.6(\mathrm{CH}, \mathrm{C}-7), 56.5\left(\mathrm{CH}_{2}, \mathrm{C}-13\right), 46.1\left(\mathrm{CH}_{3}, \mathrm{~N}\left(\mathrm{CH}_{3}\right)_{2}\right)$, $40.2\left(\mathrm{CH}_{2}, \mathrm{C}-12\right), 18.0\left(\mathrm{CH}_{3}, \mathrm{Ar}-\mathrm{CH}_{3}\right)$; The ${ }^{1} \mathrm{H}$ NMR and ${ }^{13} \mathrm{C}$ NMR data obtained were in good agreement with that reported in the literature (Sidoryk et al. 2015); ESIMS $\mathrm{m} / \mathrm{z}$ : $361.4\left(\mathrm{C}_{21} \mathrm{H}_{24} \mathrm{~N}_{6}\right)[\mathrm{M}+\mathrm{H}]^{+}$calcd. 360.4; anal. calcd. for $\mathrm{C}_{21} \mathrm{H}_{24} \mathrm{~N}_{6} \times 5 \mathrm{H}_{2} \mathrm{O} \times 4 \mathrm{HCl}$ [596.37]: C, 42.29; H, 6.42; N, 
14.09; Cl, 23.78 found: C, 42.20; H, 6.59; N, 14.00; Cl, 24.06. HPLC: $96.5 \%$.

\section{Biological studies}

\section{In vitro study}

Cell lines were purchased from American Type Culture Collection (ATCC). The cell lines A549 and NCI-H460 were maintained in RPMI-1640 (Gibco), HepG2, ACHN and CCD-11Lu were maintained in minimum essential medium (Gibco), HCT116 and HT29 were maintained in McCoy's Medium (Gibco), and A431 was maintained in Dulbecco's minimum essential medium. MCF7 was maintained in Minimum Essential Medium (Gibco) with 0.01 $\mathrm{mg} / \mathrm{ml}$ human insulin (Sigma). All culture media were supplemented with $10 \%$ fetal bovine serum (Gibco), streptomycin, and penicillin (Biowest). The cells were grown in standard conditions: $37^{\circ} \mathrm{C}, 5 \% \mathrm{CO}_{2}, 95 \%$ humidity, and passaged with $0.25 \%$ trypsin-EDTA, until $\sim 80 \%$ confluence was reached. During the course of the experiment, the microbiological purity of all cell lines was tested with the Universal Mycoplasma Detection Kit (ATCC).

The cells were seeded in 96-well cell culture plates and on the next day treated with different concentrations of the tested compounds for the next $72 \mathrm{~h}$. The cells were then incubated with 3-(4,5-dimethylthiazol-2-yl)-2,5-diphenyltetrazolium bromide at $37^{\circ} \mathrm{C}$ for $3 \mathrm{~h}$. Finally, the medium with the MTT solution was removed and formazan crystals were dissolved by adding DMSO. After mixing, the absorbency was measured at the $570 \mathrm{~nm}$ wavelength (690 $\mathrm{nm}$ reference filter) using a Microplate Reader EON (BioTek). The experiments were performed in triplicate.

\section{In vivo study}

Mice Female, 7-8-week-old Balb/c mice and 16-week-old DBA/2 mice were supplied by Mossakowski Medical Research Centre Polish Academy of Sciences (Warsaw, Poland). The mice were maintained in specific pathogenfree conditions. The experiments were performed according to the Interdisciplinary Principles and Guidelines for the Use of Animals in Research, Marketing, and Education issued by the New York Academy of Sciences' Ad Hoc Committee on Animal Research and approved by the Local Committee for Experiments with the Use of Laboratory Animals, Wroclaw, Poland.

Cell lines Murine mammary gland carcinoma 4T1 and murine lung carcinoma KLN205 cell lines were used and maintained under standard cell culture conditions (humidified atmosphere and $5 \% \mathrm{CO}_{2}$ at $37^{\circ} \mathrm{C}$ ). These cell lines were obtained from the ATCC (Rockville, Maryland, USA) and maintained at the Hirszfeld Institute of Immunology and Experimental Therapy (IIET), Wroclaw, Poland.

KLN205 cells were cultured in Eagle's minimal essential medium (IIET, Wroclaw, Poland) supplemented with $10 \%$ fetal bovine serum (GE Healthcare Life Sciences, Utah, USA), $2 \mathrm{mM}$ L-glutamine, $1 \mathrm{mM}$ sodium pyruvate, $1 \%$ of MEM nonessential amino acid solution 100x, $100 \mu \mathrm{g} / \mathrm{ml}$ streptomycin (all Sigma-Aldrich, Germany), and $100 \mathrm{IU} / \mathrm{ml}$ penicillin (Polfa Tarchomin S.A., Poland).

4T1 cells were cultured in RPMI 1640 w/GlutaMAX medium (Gibco) supplemented with $10 \%$ fetal bovine serum (GE Healthcare Life Sciences, Utah, USA), $1 \mathrm{mM}$ sodium pyruvate, $3.5 \mathrm{~g} / \mathrm{l}$ glucose, $100 \mu \mathrm{g} / \mathrm{ml}$ streptomycin (all Sigma Aldrich, Germany), and $100 \mathrm{IU} / \mathrm{ml}$ penicillin (Polfa Tarchomin S.A., Poland).

Maximum tolerated dose (MTD) In order to determine MTD, compound 1 was injected intraperitoneally (i.p.) into a healthy female BALB/c mouse (three mice per dose) at the $2.5,5,10$, and $15 \mathrm{mg}$ doses of the drug per $\mathrm{kg}$ of the body weight, five times a week for 2-3 weeks. The mice body weight was monitored every day and body weight changes were calculated. At the end of the study, the mice were killed and subjected to autopsy.

Anticancer activity in the 4T1 mammary gland carcinoma model Female Balb/c mice were inoculated orthotopically (ort.) with $50 \mu \mathrm{l}$ PBS suspension of the 4T1 cells $\left(2 \times 10^{5}\right.$ cells/mouse) derived from an in vitro culture. On the 7 th day after inoculation, when the tumors reached about 45 $\mathrm{mm}^{3}$, the mice were divided into groups $(n=10)$ and compound administration started. The compounds were administered intraperitoneally (i.p), compound $\mathbf{1}$ five times a week at the 5 and $10 \mathrm{mg} / \mathrm{kg}$ b.w. doses and cyclophosphamide three times a week at the dose of $25 \mathrm{mg} / \mathrm{kg} \mathrm{b}$.w. (all for 3 weeks). The control mice received i.p. aqua pro injection $(0.1 \mathrm{ml} / 10 \mathrm{~g}$ b.w.) in the same schedule as for compound 1.

Tumor dimensions were measured using a caliper, and the body weight of the animals was monitored three times a week. Tumor volume $\left(\mathrm{mm}^{3}\right)$ was calculated using the formula $\left(a^{2} \times b\right) / 2$, where $a=$ shortest tumor diameter in millimeters and $b=$ longest tumor diameter in millimeters. Tumor growth inhibition for each day was calculated using the formula TGI $(\%)=-\left(\left[\left(\mathrm{V}_{\mathrm{t}} / \mathrm{V}_{\mathrm{ctrl}}\right) \times 100\right]-100 \%\right)$, where $\mathrm{V}_{\mathrm{t}}$ is the mean tumor volume of the treated mice and $\mathrm{V}_{\mathrm{ctrl}}$ that of the untreated control animals. On the 29th day, all mice were killed and whole blood was collected for the morphological analysis using the Mythic 18 analyzer (PZ Cormay, PolandOrphee). Additionally, spleens, livers, kidneys, and lungs were dissected and weighed. Lungs 
were further fixed in $4 \%(\mathrm{v} / \mathrm{v})$ paraformaldehyde in the PBS solution, and the metastatic nodes were counted.

Anticancer activity in the murine lung carcinoma KLN205 model Female DBA/2 mice were inoculated $s u b$ cutaneously (s.c.) with the KLN205 cells $\left(8.5 \times 10^{5}\right.$ cells/ mouse) derived from an in vitro culture. On the 7 th day after the inoculation, when tumors reached about $60 \mathrm{~mm}^{3}$, the mice were divided into groups $(n=7-8)$ and compound administration started. The compounds were administered intraperitoneally (i.p): compound $\mathbf{1}$ five times a week at the 10 and $20 \mathrm{mg} / \mathrm{kg} \mathrm{b.w.} \mathrm{doses} \mathrm{and} \mathrm{cyclophosphamide} \mathrm{once} \mathrm{a}$ week at the dose of $100 \mathrm{mg} / \mathrm{kg}$ b.w. (all for 2.5 weeks). The control mice received i.p. aqua pro injection $(0.1 \mathrm{ml} / 10 \mathrm{~g} \mathrm{~b}$. w.) in the same schedule as for compound $\mathbf{1}$.

Tumor dimensions were measured using a caliper, and the body weight of the animals was monitored three times a week. Tumor volume $\left(\mathrm{mm}^{3}\right)$ was calculated using the formula described above. On day 25, all mice were killed and whole blood was collected for the morphological analysis using the Mythic 18 analyzer (Orphee). The whole blood was further centrifuged $\left(2000 \mathrm{xg}, 4^{\circ} \mathrm{C}, 15 \mathrm{~min}\right)$ for plasma and analyzed for biochemical parameters (alanine aminotransferase (ALT), aspartate aminotransferase (AST), lactate dehydrogenase (LDH), urea and creatinine (CREA)) using the Cobas c111 analyzer (Roche). Additionally, livers and kidneys were dissected and weighed.

MTD of compound 1 determination in BALB/c mice Compound 1 was injected i.p. at the doses of 2.5, 5, 10, and $15 \mathrm{mg}$ per $\mathrm{kg}$ body weight, five times a week for 2-3 weeks. No toxicity of the $2.5 \mathrm{mg} / \mathrm{kg}$ b.w. dose was observed. Doses 5 and $10 \mathrm{mg} / \mathrm{kg} \mathrm{b.w.} \mathrm{had} \mathrm{low} \mathrm{toxicity} \mathrm{for} \mathrm{the} \mathrm{Balb/c} \mathrm{mice}$ (max. body weight loss reached 7 and 9.5\%, respectively). Compound 1 at the dose of $15 \mathrm{mg} / \mathrm{kg} \mathrm{b.w}$. was toxic for the Balb/c mice. Max. body weight loss reached $21 \%$ and one mice died.

\section{Results}

\section{Studies on the efficient methods for the construction of guanidine-substituted indolo[2,3-b]quinolines}

As it had been shown in our previous studies (Sidoryk et al. 2015), the presence of the guanidine group is a very important element affecting the cytotoxicity and selectivity of the indolo[2,3-b]quinoline guanidine derivatives. Until now the indolo[2,3-b]quinoline guanidine derivative (1) has been prepared in the following established sequence: the
Scheme 1 The standard synthesis method of the indolo [2,3-b]quinoline guanidine derivative

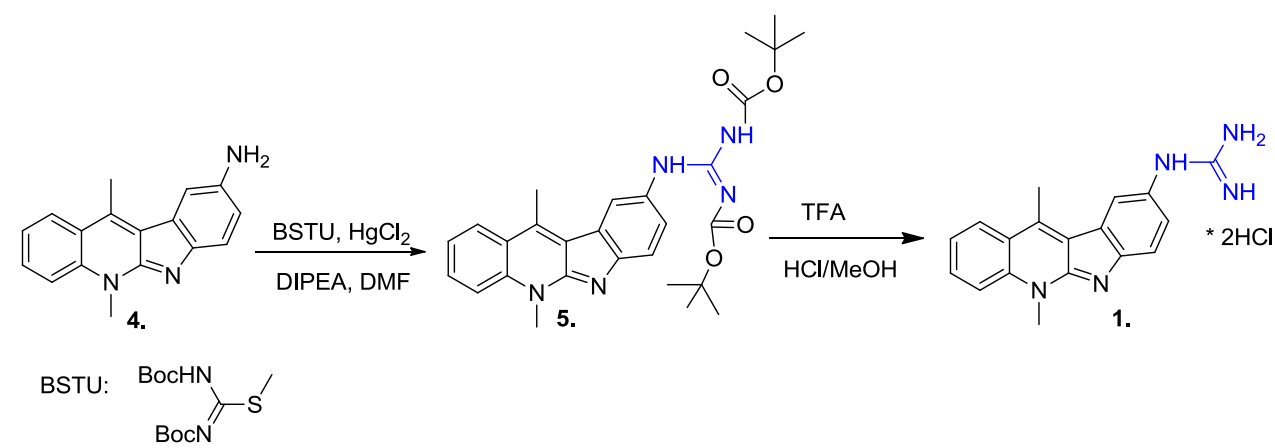

Scheme 2 The reagents used for the optimization of compound 4 guanidylation process

<smiles>Cc1c2c3cc(NC(=N)N)ccc3nc-2n(C)c2ccccc12</smiles>

Guanylation reagents:<smiles></smiles><smiles></smiles><smiles>CC(C)(C)OC(=O)NC(=NS(=O)(=O)C(F)(F)F)NC(=O)OCc1ccccc1</smiles> 
amidination of indolo[2,3-b]quinoline-amine (4) using BSTU ( $N, N^{\prime}$-Bis(tert-butyloxycarbonyl)-S-methylisothiourea) as the guanylation reagent and the removal of Boc protection groups with trifluoroacetic acid (Scheme 1).

The limitations of this approach include a relatively low yield of amidination (50-60\%) and the release of gaseous methanethiol $\left(\mathrm{CH}_{3} \mathrm{SH}\right)$ with a distinctive stench during the reaction. Thus, we have decided to search for more efficient synthetic methods to prepare compounds $\mathbf{1}$ and $\mathbf{3}$.

After a detailed literature search, numerous reagents leading to obtain different guanylate compounds have been found. Common guanidylation methods use mono-, di-Boc, or mono-and di-Z-derivatives of $1 \mathrm{H}$-pyrazole-1-carboxamidine (Bernatowicz et al. 1992; Massimba-Dibama et al. 2015). However, the PCA reagent (1H-pyrazole-1-carboxamidine) seemed to be the most favorable, because it enables the introduction of the guanidine group in a single step and does not require the removal of any protecting group. This may increase the overall yield of the entire process and eliminate the problem of gaseous thiol released during the BSTU guanidylation. We have started to test commercially available reagents and literature procedures using PCA ( $1 \mathrm{H}$-pyrazole-1carboxamidine hydrochloride), DMPCA (3,5-dimethyl-1pyrazolylformaminidium nitrate), $N$-Boc-1H-pyrazole-1-carboxamidine, and 1,3-di-Boc-2-(trifluoromethylsulfonyl)guanidine (Scheme 2) in the guanylation of 4 (Baker et al. 2004). The progress of the reactions was monitored by TLC methods. For the PCA or DMPCA reagents, HPLC methods were applied to examine 1 formation.

While using the PCA or DMPCA as guanylation reagents, a prolonged reaction time was essential to the consumption of the starting material 4 (Table 1). For both reagents, the minimum reaction time was determined as
10 days, although even after that time the traces of substrate 4 were observed in the reaction mixtures. Moreover, the HPLC analysis revealed the presence of a large number of unknown impurities in the mixture, especially for DMPCA, when only $44.7 \%$ of the expected product 1 was observed. The long reaction time and the tendency to form various impurities eliminated PCA and DMPCA procedures as ineffective for the synthesis of indolo[2,3-b]quinoline guanidine derivatives. $\mathrm{N}$-Boc- $1 \mathrm{H}$-pyrazole-1-carboxamidine was the next examined reagent. In standard conditions, at ambient temperature, the reaction progress was not observed in time. Although we prolonged the reaction time to 5 days and increased the temperature to $50-60^{\circ} \mathrm{C}$, only unchanged substrate $\mathbf{4}$ was detected in the TLC method.

During our studies, the best result was achieved when a completely protected guanidine derivative 1,3-di-Boc-2(trifluoromethylsulfonyl)guanidine $\quad\left(N, N^{\prime}\right.$-di-Boc- $N^{\prime \prime}$-triflylguanidine) was applied as a guanylation reagent. The guanylation method with $N, N^{\prime}$-di-Boc- $N^{\prime \prime}$-triflylguanidine seems to be the most efficient for the guanidylation of amines. Thus, it is commonly applied as the method of choice for the reaction carried out in a solution or on solid phase (Feichtinger et al. 1998a, b). Generally, guanidylations with pyrazole-1-carboxamidines and $S$-alkylisothioureas are kinetically slower in comparison to that using $N, N^{\prime}$-di-Boc- $N^{\prime \prime}$-triflylguanidine. Moreover, simple preparation of $N, N^{\prime}$-di-Boc- $N^{\prime \prime}$-triflylguanidine from a commercially available source is also conceivable, which makes this guanidylation reagent very attractive for the chemists (Baker and Goodman 1999). The process of guanidylation of $\mathbf{4}$ through $N, N^{\prime}$-di-Boc- $N^{\prime \prime}$-triflylguanidine was performed similarly to the known procedures (Magri et al. 2015), i.e., in DCM, in the presence of DIPEA, at room
Table 1 The results of the guanidylation process of $\mathbf{4}$ according to the HPLC methods

\begin{tabular}{|c|c|c|c|c|}
\hline \multirow[t]{2}{*}{ Guanylation reagent } & \multirow[t]{2}{*}{ Reaction time } & \multicolumn{3}{|l|}{ HPLC $^{\mathrm{a}}$} \\
\hline & & $\begin{array}{l}\text { Substrate } 4 \\
(\mathrm{Rt}=17.0)(\%)\end{array}$ & $\begin{array}{l}\text { Product } 1 \\
(\mathrm{Rt}=19.1)(\%)\end{array}$ & $\begin{array}{l}\text { Intermediate } \mathbf{5} \\
(\mathrm{Rt}=30.8)\end{array}$ \\
\hline \multirow[t]{5}{*}{ PCA } & $24 \mathrm{~h}$ & 75.5 & 18.5 & - \\
\hline & $48 \mathrm{~h}$ & 51.8 & 38.5 & - \\
\hline & $72 \mathrm{~h}$ & 34.2 & 54.5 & - \\
\hline & 10 days & 15.5 & 67.2 & - \\
\hline & 14 days & 11.9 & 68.3 & - \\
\hline \multirow[t]{4}{*}{ DMPCA } & $24 \mathrm{~h}$ & 81.7 & 7.5 & - \\
\hline & $48 \mathrm{~h}$ & 64.8 & 19.5 & - \\
\hline & $72 \mathrm{~h}$ & 49.9 & 30.4 & - \\
\hline & 10 days & 16.5 & 44.7 & - \\
\hline$N$-Boc-1H-pyrazole-1-carboxamidine & $48 \mathrm{~h}$ & & $-{ }^{b}$ & - \\
\hline$N, N^{\prime}$-di-Boc- $N^{\prime \prime}$-triflylguanidine & $5 \mathrm{~h}$ & - & 97.38 & $94.82 \%$ \\
\hline
\end{tabular}

${ }^{\text {a }}$ HPLC methods were described in the Experimental section

${ }^{b}$ According to the TLC method

Bold values are the best result observed in the experiment 
Fig. 2 Chromatogram of compound 1 obtained with an Experimental Section HPLC method described in the



Scheme 3 Reagents and conditions: a 1,3-di-Boc-2(trifluoromethylsulfonyl) guanidine, DIPEA, DCM, rt. b TFA, $\mathrm{HCl} / \mathrm{MeOH}$
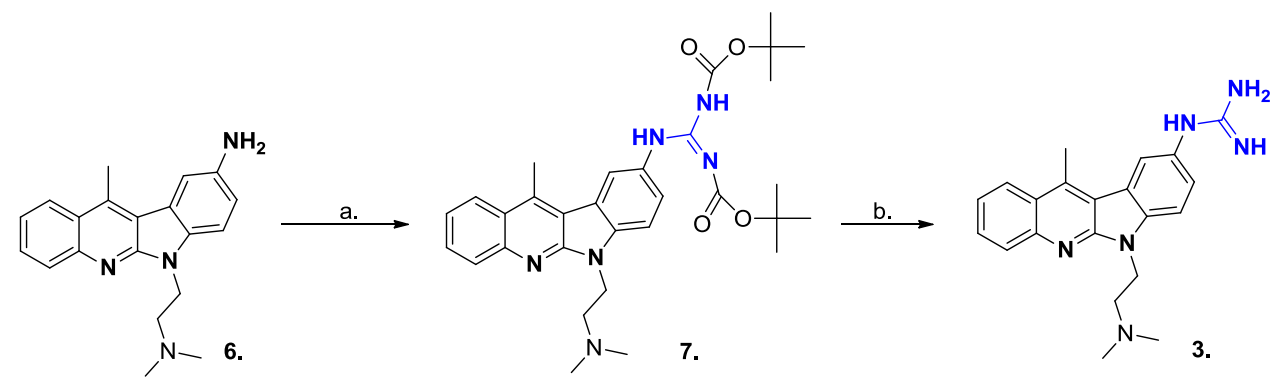

All three tested compounds showed cytotoxic properties (Fig. 3). However, compound $\mathbf{3}$ seemed to be significantly weaker than 1 and the DiMIQ reference compound. The most important differences in the activity against specific types of human cell lines were observed for compound $\mathbf{1}$. The MCF7 breast and A549 lung carcinoma cells turned out to be the most sensitive to $\mathbf{1}$, with $\mathrm{IC}_{50}=0.5 \mu \mathrm{M}$ and 0.19 $\mu \mathrm{M}$, respectively. These results appeared to be $5-15$ times higher in comparison to that collected for DiMIQ $\left(\mathrm{IC}_{50}=\right.$ 3.4 and $2.74 \mu \mathrm{M}$ ). For two investigated cell lines, i.e., ACHN derived from human kidney cancer and HepG2 derived from human liver cancer, compound 1 exhibited the weakest cytotoxic properties among all studied compounds, while DiMIQ was the most active. These visible differences seem to be noteworthy and would present an interesting area for further scientific investigation in order to find specific biomarkers influencing sensitivity to particular cell lines. The activities of compounds $\mathbf{1}$ and DiMIQ against other investigated cell lines were comparable on the level of a few micromoles. Despite displaying high cytotoxicity against normal cells $(\mathrm{CCD} 11 \mathrm{Lu})$, compound $\mathbf{1}$ was selected for extended in vivo studies because of its interesting in vitro profile against breast and lung cancer cell lines.

In vivo study

Compound 1 and cyclophosphamide (Endoxan, Baxter) were dissolved in aqua pro injection prior to use.

Anticancer activity of compound $\mathbf{1}$ in the 4T1 mammary gland carcinoma model Female Balb/c mice were inoculated orthotopically (ort.) with the 4T1 cells $\left(2 \times 10^{5}\right.$ cells/ 
Fig. 3 Comparison of the antiproliferative activity $\left(\mathrm{IC}_{50}\right)$ of the indolo[2,3-b]quinoline derivatives 1, 3, and DiMIQ

Fig. 4 Kinetics of the 4T1 tumor growth (a) and number of metastatic nodes in lungs (b) in $\mathrm{Balb} / \mathrm{c}$ mice treated with compound 1. Compound 1 was administered IP at the doses of 5 and $10 \mathrm{mg} / \mathrm{kg}$ b.w. five times a week; cyclophosphamide was administered IP at the dose of $25 \mathrm{mg} / \mathrm{kg}$ b.w. three times a week; asterisk indicates the statistical significance vs the control group $(p<0.05$;

Mann-Whitney U test, Statistica 10.1)
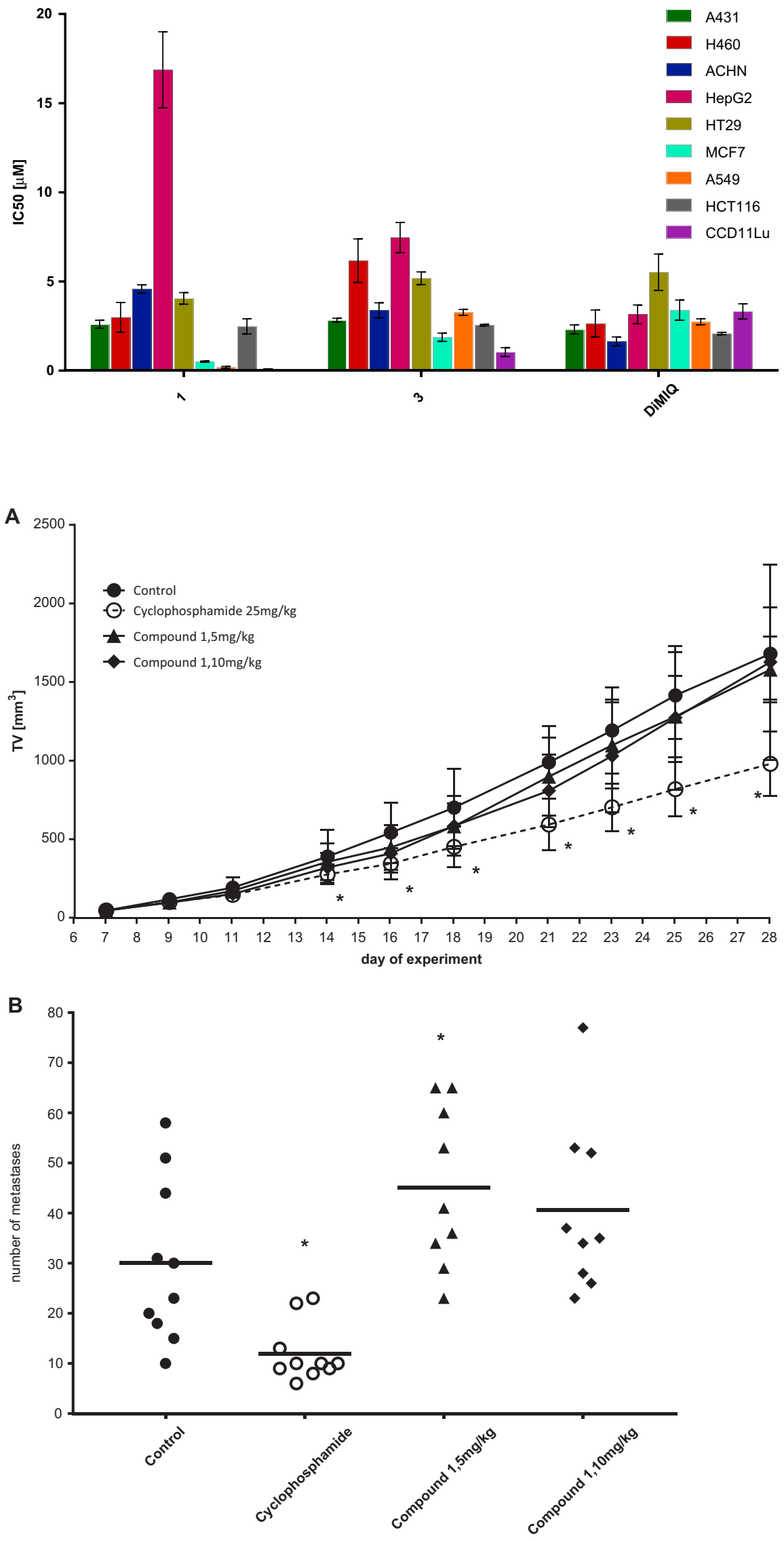
mouse). On the 7th day after cell inoculation, compounds' administration began (intraperitoneally). Compound $\mathbf{1}$ was administered five times a week at the strength of 5 and 10 $\mathrm{mg} / \mathrm{kg}$ b.w. The anticancer activity of compound $\mathbf{1}$ was not observed (Fig. 4a), only cyclophosphamide at the dose of $25 \mathrm{mg} / \mathrm{kg}$ b.w (three times a week) inhibited 4T1 tumor growth by $30-42 \%$. At the end of the experiment (day 29), all mice were killed. Whole blood was collected for the morphological analysis and spleens, livers, kidneys, and lungs were dissected and weighed. Additionally, metastatic nodes in the lungs were counted. Compound $\mathbf{1}$ increased the number of tumor metastasis in the lungs (Fig. 4b), but did not influence the lungs' weight (Table 2). Cyclophosphamide diminished the number of metastatic nodes in lungs by $60 \%$ (Fig. 4b), and also the weight of lungs (Table 2 ) was lower in comparison to that in the control mice.

The overall condition of the mice bodies was monitored, and no body loss was observed (data not shown). In groups that received compound $\mathbf{1}$, the weight of the liver and kidneys was similar to the control groups (Table 2). No changes in the number of erythrocytes and in the level of hemoglobin were observed in the treated groups (Table 2). After the treatment with compound $\mathbf{1}$ or cyclophosphamide, increased levels of hematocrit, $\mathrm{MCV}$ and number of platelets were observed. Compound $\mathbf{1}$ increased the number of leukocytes (WBC), but the percent of monocytes was higher and the percent of granulocytes was lower than that in the control mice (Table 2).

Anticancer activity of compound $\mathbf{1}$ in the KLN205 murine lung carcinoma model Compound $\mathbf{1}$ was administered five times a week at the strength of 10 and $20 \mathrm{mg} / \mathrm{kg} \mathrm{b.w}$. starting from the 7th day after the KLN205 cells' inoculation. The anticancer activity of compound $\mathbf{1}$ was observed at the end of the experiment (Fig. 5), tumor growth inhibition reached $27-34 \%$ at the dose of $10 \mathrm{mg} / \mathrm{kg}$ and about $37 \%$ at the dose of $20 \mathrm{mg} / \mathrm{kg}$. Toxic effects of compound 1 were observed in tumor-bearing DBA/2 mice. Body weight loss (Fig. 6b) was $9-14 \%$ at the $10 \mathrm{mg} / \mathrm{kg}$ dose and $10-20 \%$ at the $20 \mathrm{mg} / \mathrm{kg}$ dose (one mouse died on the last day of the experiment). Compound $\mathbf{1}$ decreased the number of erythrocytes as well as the levels of hemoglobin, hematocrit (which may demonstrate side effect of the treatment, such as anemia), and creatinine (CRE) in the blood in comparison to the control group (Table 3). The percentage of lymphocytes increased and the percentage of granulocytes decreased, but the total number of leukocytes was similar to that of the control group. Diminished liver weight in the group that received compound $\mathbf{1}$ at the $20 \mathrm{mg} / \mathrm{kg}$ dose was observed (Table 3). Cyclophosphamide used as a positive
Table 2 The influence of compound 1 on the blood morphology and organ weight in 4T1 tumor-bearing mice

\begin{tabular}{lllll}
\hline & Control & $\begin{array}{l}\text { Cyclophosphamide } \\
25(\mathrm{mg} / \mathrm{kg})\end{array}$ & $\begin{array}{l}\text { Compound } \mathbf{1} \\
5(\mathrm{mg} / \mathrm{kg})\end{array}$ & $\begin{array}{l}\text { Compound 1 } \\
10(\mathrm{mg} / \mathrm{kg})\end{array}$ \\
\hline WBC $\left(10^{3} / \mu \mathrm{l}\right)$ & $232.6 \pm 64.7$ & $244.2 \pm 82.2$ & $298.9 \pm 78.9$ & $342.4 \pm 110.6^{*}$ \\
LIMF $\left(10^{3} / \mu \mathrm{l}\right)$ & $22.8 \pm 5.3$ & $18.9 \pm 3.9$ & $33.6 \pm 6.1^{*}$ & $36.7 \pm 8.9^{*}$ \\
MON $\left(10^{3} / \mu \mathrm{l}\right)$ & $11.4 \pm 3$ & $14.9 \pm 4.1$ & $23.9 \pm 7.7^{*}$ & $29.7 \pm 10.4^{*}$ \\
GRAN $\left(10^{3} / \mu \mathrm{l}\right)$ & $198.3 \pm 60.1$ & $210.4 \pm 75.0$ & $241.3 \pm 67.3$ & $276.0 \pm 92.6$ \\
LIMF $(\%)$ & $10.2 \pm 2.4$ & $8.1 \pm 1.5$ & $11.6 \pm 2.1$ & $11.0 \pm 1.4$ \\
MON $(\%)$ & $5.0 \pm 0.4$ & $6.4 \pm 1.3^{*}$ & $7.9 \pm 0.8^{*}$ & $8.7 \pm 1.0^{*}$ \\
GRAN $(\%)$ & $84.8 \pm 2.6$ & $85.5 \pm 2.7$ & $80.4 \pm 2.1^{*}$ & $80.3 \pm 2.1^{*}$ \\
Erythrocytes $\left(10^{6} / \mu \mathrm{l}\right)$ & $8.9 \pm 0.7$ & $9.4 \pm 0.8$ & $9.1 \pm 0.6$ & $9.6 \pm 1.3$ \\
hemoglobin $(\mathrm{g} / \mathrm{dl})$ & $15.6 \pm 1.4$ & $17.0 \pm 1.3$ & $16.4 \pm 1.2$ & $17.5 \pm 2.4$ \\
hematocrit $(\%)$ & $42.7 \pm 4.4$ & $47.5 \pm 3.4^{*}$ & $45.4 \pm 3.0$ & $49.4 \pm 6.8^{*}$ \\
MCV (fL) & $47.9 \pm 1.5$ & $50.5 \pm 2.3^{*}$ & $50.1 \pm 1.8^{*}$ & $51.2 \pm 2.1^{*}$ \\
MCH $(\mathrm{pg})$ & $17.5 \pm 0.7$ & $18.1 \pm 0.4$ & $18.1 \pm 0.4$ & $18.1 \pm 0.3^{*}$ \\
MCHC $(\mathrm{g} / \mathrm{dl})$ & $36.7 \pm 1.5$ & $35.8 \pm 1.4$ & $36.2 \pm 1.6$ & $35.5 \pm 1.4$ \\
RDW $(\%)$ & $16.5 \pm 0.4$ & $18.4 \pm 1.4^{*}$ & $16.4 \pm 1.0$ & $16.5 \pm 0.9$ \\
platelets $\left(10^{3} / \mu \mathrm{L}\right)$ & $618.7 \pm 146.7$ & $852.4 \pm 126.3^{*}$ & $745.3 \pm 109.8$ & $737.8 \pm 260.7$ \\
Liver $(\mathrm{g})$ & $1.150 \pm 0.1$ & $1.214 \pm 0.17$ & $1.187 \pm 0.14$ & $1.230 \pm 0.22$ \\
Spleen $(\mathrm{g})$ & $0.809 \pm 0.13$ & $0.814 \pm 0.22$ & $0.703 \pm 0.07^{*}$ & $0.731 \pm 0.12$ \\
Kidneys $(\mathrm{g})$ & $0.265 \pm 0.03$ & $0.278 \pm 0.03$ & $0.270 \pm 0.03$ & $0.258 \pm 0.04$ \\
Lung $(\mathrm{g})$ & $0.325 \pm 0.1$ & $0.228 \pm 0.03^{*}$ & $0.330 \pm 0.08$ & $0.327 \pm 0.08$ \\
\hline
\end{tabular}

Control and groups treated with cyclophosphamide at the dose of $25 \mathrm{mg} / \mathrm{kg}(3 \mathrm{t} / \mathrm{w})$ and compound $\mathbf{1}$ at the doses of 5 and $10 \mathrm{mg} / \mathrm{kg}(5 \mathrm{t} / \mathrm{w})$

* Statistical significance vs. the control group, $(p<0.05$; Mann-Whitney U test, Statistica 10.1) 
Fig. 5 Kinetics of the KLN205 tumor growth in DBA/2 mice treated with compound $\mathbf{1}$.

Compound 1 was administered

IP at the doses of 10 and $20 \mathrm{mg} /$

$\mathrm{kg}$ b.w. five times a week; cyclophosphamide was administered IP at the dose of $100 \mathrm{mg} / \mathrm{kg}$ b.w. once a week; asterisk indicates the statistical significance vs. the control group $(p<0.05$; Mann-Whitney U test, Statistica 10.1)



control at the $100 \mathrm{mg} / \mathrm{kg} \mathrm{b.w}$. dose (once a week) inhibited tumor growth by $27-43 \%$ (Fig. 5) and slightly decreased body weight $(7-10 \%)$. Side effects of the treatment, such as a decrease in the number of erythrocytes and leukocytes (WBC) (an increased percentage of lymphocytes and a decreased percentage of monocytes and granulocytes was observed) were also observed. The cyclophosphamide treatment also diminished the levels of hemoglobin, hematocrit, CRE, as well as alanine aminotransferase (ALT), aspartate aminotransferase (AST), and lactate dehydrogenase $(\mathrm{LDH})$ in the blood. Liver weight was higher in this group.

\section{Discussion}

During our previous studies it had been demonstrated that the guanidylation by $N, N^{\prime}$-Bis(tert-butyloxycarbonyl)- $S$ methylisothiourea allows to obtain samples of indolo[2,3-b] quinoline guanidine derivatives for biological screening in average yields. However, this approach seemed to be problematic in the production of gram samples of compounds because of the mephitic methyl mercaptan release. In the present paper an optimization of the guanidylation process in order to obtain the guanidine derivatives of indolo[2,3-b] quinoline has been discussed. The effectiveness of the guanylation using common guanylation reagents, such as $1 H$-pyrazole-1-carboxamidine hydrochloride, 3,5-dimethyl1-pyrazolylformaminidium nitrate, $N$-Boc- $1 H$-pyrazole-1carboxamidine, and 1,3-di-Boc-2-(trifluoromethylsulfonyl) guanidine ( $N, N^{\prime}$-di-Boc- $N^{\prime \prime}$-triflylguanidine), was verified. As a result of our studies, a high-yield procedure with $N, N^{\prime}$ di-Boc- $N^{\prime \prime}$-triflylguanidine was applied to synthesize $N$ - guanyl- $N$-(5,11-dimethyl-5H-indolo[2,3-b]qinolin-9-yl)amine dihydrochloride $\mathbf{1}$ which had been selected for specific in vitro and in vivo biological research. Compound $\mathbf{1}$ was obtained in a gram scale in the presence of $N, N^{\prime}$-diBoc- $N$ "-triflylguanidine reagent with the overall yield of 80 and $97.38 \%$ purity according to the HPLC method. Then, a comprehensive in vitro study on the antiproliferative activity of DiMIQ, the reference compound, and two guanidine analogs $\mathbf{1}$ and $\mathbf{3}$ against eight cancer cell lines was completed. The highest activity was shown by compound $\mathbf{1}$ against $\mathrm{A} 549$ and MCF7 lines with the $\mathrm{IC}_{50}$ values equal to $0.19 \mu \mathrm{M}$ and $0.5 \mu \mathrm{M}$, respectively. Therefore, compound 1 was selected for further investigations in the in vivo mouse models of 4T1 mammary gland carcinoma and KLN205 murine lung carcinoma. As far as the 4T1 model is concerned, we did not observe any anticancer activity of $\mathbf{1}$ at the 5 and $10 \mathrm{mg} / \mathrm{kg}$ b.w. doses, whereas the anticancer effect was observed in the KLN205 model. The tumor growth inhibition induced by compound 1 reached $37 \%$ at the $20 \mathrm{mg} / \mathrm{kg}$ dose, which was comparable to that of cyclophosphamide used as a positive control. This commonly used therapeutic agent inhibited tumor growth in mice by $27-43 \%$ at the dose of $100 \mathrm{mg} / \mathrm{kg}$. Moreover, biochemistry research based on monitoring blood parameters such as alanine aminotransferase ALT, aspartate aminotransferase AST, lactate dehydrogenase $\mathrm{LDH}$, and urea and creatinine CREA was performed. Compound 1 decreased the number of erythrocytes and the levels of hemoglobin, hematocrit, as well as creatinine in the blood in comparison to the control group. Although the total number of leukocytes was similar to that in the control group, an increase in lymphocytes and a decrease in granulocytes were observed. A similar effect was measured for cyclophosphamide. 
Fig. 6 Body weight (a) and body weight changes (b) in DBA/2 mice bearing KLN205 tumors treated with compound 1. Compound 1 was administered IP at the doses of 10 and $20 \mathrm{mg} / \mathrm{kg}$ b.w. five times a week; cyclophosphamide was administered IP at the dose of $100 \mathrm{mg} / \mathrm{kg}$ b.w. once a week
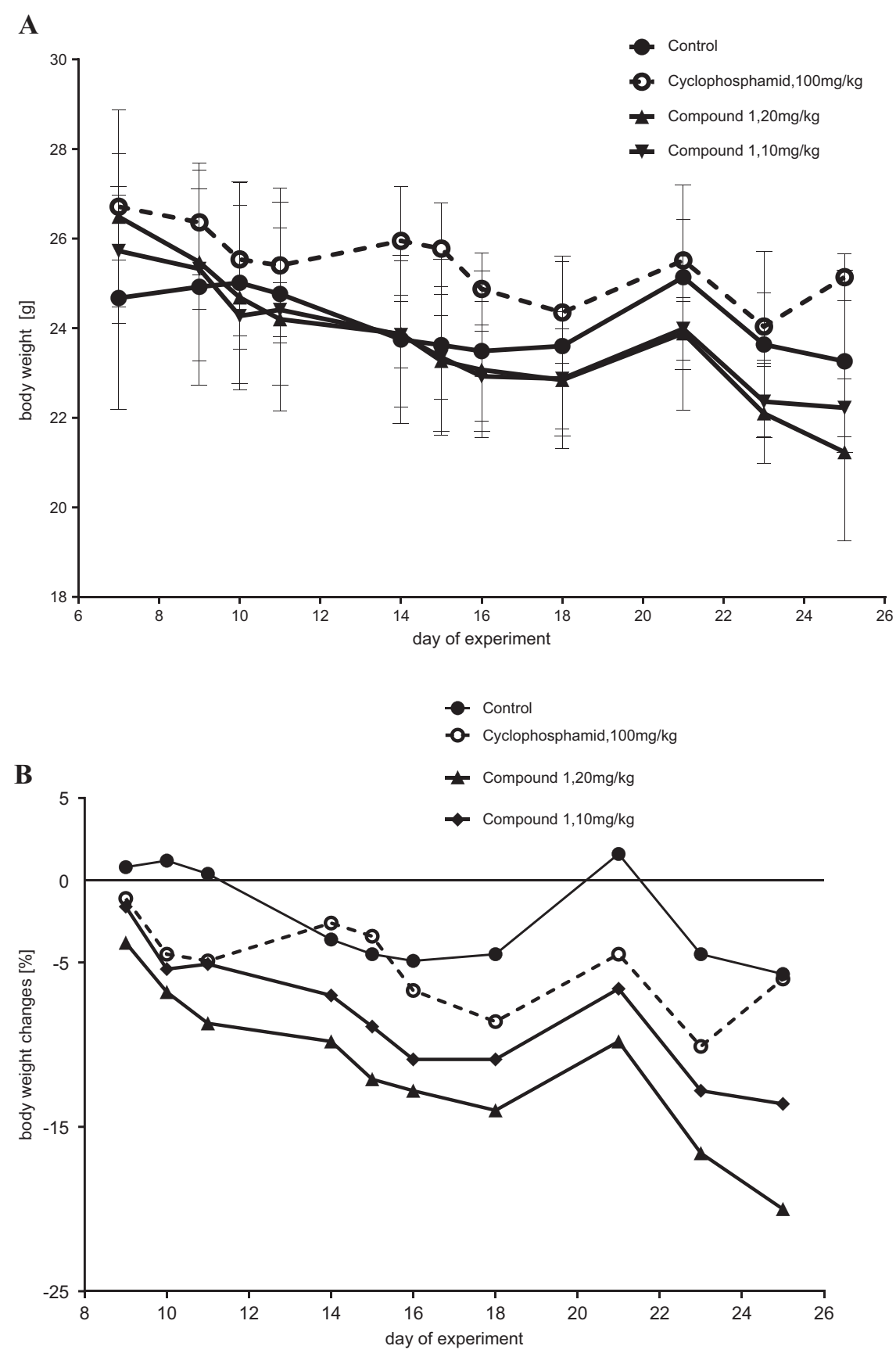

Although cancer cell lines have a prominent role in the initial stages of drug discovery, it was found that even cancer-specific drugs do not show higher efficacies in the cell lines representing respective tissues (Jaeger et al. 2015). Thus, we verified the results of our enhanced in vivo studies in two mouse models, which led us to the conclusion that compound $\mathbf{1}$ displayed an anticancer activity in the KLN205 mouse model. This result qualified guanidine derivative $\mathbf{1}$, which is an effective inducer of apoptosis and does not induce hemolysis (Sidoryk et al. 2015), for further investigations in the cell line xentograft models CLX and/or patient derived tumor xenografts (PDTX) which resemble tumors growing in a patient.

Although the core structure of DiMIQ meets all the criteria for the DNA intercalation and TOPO2 inhibition, previous studies had shown that TOPO2 may not be the main cellular target for different DiMIQ analog compounds. Therefore, for the conjugates containing the guanidine group, a study of biological interactions with the tumor models in order to find the selectivity factors related to specific signaling pathways responsible for the cancer growth is intended. 
Table 3 Blood morphology, biochemistry, and organ weight in mice bearing KLN205 tumors

\begin{tabular}{|c|c|c|c|c|}
\hline & Control & $\begin{array}{l}\text { Cyclophosphamide } \\
100(\mathrm{mg} / \mathrm{kg})\end{array}$ & $\begin{array}{l}\text { Compound } 1 \\
10(\mathrm{mg} / \mathrm{kg})\end{array}$ & $\begin{array}{l}\text { Compound } 1 \\
20(\mathrm{mg} / \mathrm{kg})\end{array}$ \\
\hline $\operatorname{WBC}\left(10^{3} / \mu \mathrm{l}\right)$ & $33.2 \pm 6.0$ & $3.5 \pm 0.8^{*}$ & $37.5 \pm 17.4$ & $27.8 \pm 17.5$ \\
\hline $\operatorname{LIMF}\left(10^{3} / \mu \mathrm{l}\right)$ & $15.0 \pm 6.0$ & $2.4 \pm 0.7^{*}$ & $24.5 \pm 16.2$ & $17.4 \pm 15.2$ \\
\hline $\operatorname{MON}\left(10^{3} / \mu \mathrm{l}\right)$ & $3.5 \pm 0.8$ & $0.3 \pm 0.1^{*}$ & $3.0 \pm 0.5$ & $2.4 \pm 0.6^{*}$ \\
\hline GRAN $\left(10^{3} / \mu \mathrm{l}\right)$ & $14.7 \pm 2.8$ & $0.8 \pm 0.2^{*}$ & $10.0 \pm 2.1^{*}$ & $8.0 \pm 2.5^{*}$ \\
\hline LIMF $(\%)$ & $44.4 \pm 11.8$ & $68.3 \pm 5.4^{*}$ & $59.7 \pm 15.0$ & $54.2 \pm 19.4$ \\
\hline $\operatorname{MON}(\%)$ & $10.7 \pm 2.5$ & $8.0 \pm 1.2^{*}$ & $9.6 \pm 4.3$ & $10.9 \pm 5.3$ \\
\hline GRAN (\%) & $45.0 \pm 9.5$ & $23.7 \pm 4.2^{*}$ & $30.7 \pm 10.8^{*}$ & $34.9 \pm 14.1$ \\
\hline Erythrocytes $\left(10^{6} / \mu \mathrm{l}\right)$ & $7.3 \pm 1.1$ & $5.9 \pm 0.7^{*}$ & $4.7 \pm 1.3^{*}$ & $5.8 \pm 1.5$ \\
\hline hemoglobin (g/dl) & $11.4 \pm 1.2$ & $9.4 \pm 0.9^{*}$ & $8.4 \pm 2.1^{*}$ & $10.1 \pm 1.8$ \\
\hline hematocrit (\%) & $31.4 \pm 3.0$ & $25.0 \pm 2.6^{*}$ & $24.1 \pm 5.1^{*}$ & $27.7 \pm 4.0$ \\
\hline MCV (fL) & $43.5 \pm 4.6$ & $42.7 \pm 2.6$ & $51.9 \pm 5.4$ & $49.7 \pm 7.3$ \\
\hline $\mathrm{MCH}(\mathrm{pg})$ & $15.8 \pm 1.4$ & $16.1 \pm 0.8$ & $17.9 \pm 1.1$ & $17.9 \pm 1.9$ \\
\hline $\mathrm{MCHC}(\mathrm{g} / \mathrm{dl})$ & $36.4 \pm 1.0$ & $37.7 \pm 0.6$ & $34.5 \pm 1.8$ & $36.3 \pm 1.3$ \\
\hline RDW (\%) & $22.0 \pm 2.6$ & $22.2 \pm 2.0$ & $24.3 \pm 2.5$ & $26.5 \pm 3.1$ \\
\hline platelets $\left(10^{3} / \mu \mathrm{l}\right)$ & $817.3 \pm 67.7$ & $1477.0 \pm 97.7^{*}$ & $750.3 \pm 125.7$ & $942.8 \pm 38.3$ \\
\hline ALT (U/l) & $29.6 \pm 3.9$ & $23.0 \pm 1.2 *$ & $25.6 \pm 2.5^{*}$ & $24.8 \pm 1.6^{*}$ \\
\hline AST (U/l) & $98.1 \pm 11.2$ & $66.6 \pm 8.6^{*}$ & $86.8 \pm 9.7^{*}$ & $95.1 \pm 12.1$ \\
\hline LDH (U/l) & $429.7 \pm 67.6$ & $325.5 \pm 62.0^{*}$ & $406.4 \pm 61.9$ & $457.1 \pm 85.6$ \\
\hline CRE (umol/l) & $6.3 \pm 1.2$ & $3.1 \pm 0.8^{*}$ & $5.6 \pm 1.9$ & $4.4 \pm 1.1 *$ \\
\hline urea $(\mathrm{mmol} / \mathrm{l})$ & $6.2 \pm 1.6$ & $6.1 \pm 1.1$ & $7.0 \pm 1.8$ & $6.2 \pm 1.1$ \\
\hline Liver (g) & $1.473 \pm 0.09$ & $1.666 \pm 0.11 *$ & $1.384 \pm 0.11$ & $1.275 \pm 0.16^{*}$ \\
\hline Kidneys (g) & $0.344 \pm 0.04$ & $0.366 \pm 0.02$ & $0.327 \pm 0.04$ & $0.328 \pm 0.04$ \\
\hline
\end{tabular}

Control and groups treated by cyclophosphamide at the dose of $100 \mathrm{mg} / \mathrm{kg}(1 \mathrm{t} / \mathrm{w})$ or compound $\mathbf{1}$ at the doses of 10 and $20 \mathrm{mg} / \mathrm{kg}(5 \mathrm{t} / \mathrm{w})$

* Statistical significance vs. the control group, $(p<0.05$; Mann-Whitney U test, Statistica 10.1)

\section{Conclusions}

Summarizing, an efficient of the guanidylation process for obtaining guanidine derivatives of indolo[2,3-b]quinoline $\mathbf{1}$, using $N, N^{\prime}$-di-Boc- $N^{\prime \prime}$-triflylguanidine has been performed. Compound 1, produced in a gram scale, was next tested for its anticancer activity in vivo. The biological studies proved that $\mathbf{1}$ has a high anticancer activity against KLN205 murine lung carcinoma with a $37 \%$ tumor growth inhibition at the $20 \mathrm{mg} / \mathrm{kg}$ dose. These promising results of our conducted research encourage further studies using PDTX cancer models.

\section{Compliance with ethical standards}

Conflict of interest The authors declare that they have no competing interests.

Ethical statement All applicable international, national, and/or institutional guidelines for the care and use of animals were followed.

Open Access This article is distributed under the terms of the Creative Commons Attribution 4.0 International License (http://crea tivecommons.org/licenses/by/4.0/), which permits unrestricted use, distribution, and reproduction in any medium, provided you give appropriate credit to the original author(s) and the source, provide a link to the Creative Commons license, and indicate if changes were made.

\section{References}

Baker TJ, Goodman M (1999) Synthesis of biologically important guanidine-containing molecules using triflyl-diurethane protected guanidines. Synthesis 1:1423-1426

Baker TJ, Tomioka M, Goodman M (2004) Preparation and use of N, $\mathrm{N}^{\prime}$-di-Boc-N"-triflylguanidine. Org Synth Coll 10:266

Bernatowicz MS, Wu Y, Matsueda GR (1992) 1H-pyrazole-1carboxamidine hydrochloride an attractive reagent for guanylation of amines and its application to peptide synthesis. J Org Chem 57:2497-2502

Chari RVJ (2008) Targeted cancer therapy: conferring specificity to cytotoxic drugs. Acc Chem Res 41:98-107

Coffey DS, McDonald AI, Overman LE, Rabinowitz MH, Renhowe PA (2000) A practical entry to the crambescidin family of guanidine alkaloids. Enantioselective total syntheses of ptilomycalin A, crambescidin 657 and its methyl ester (Neofolitispates 2), and Crambescidin 800. J Am Chem Soc 122:4893-4903 
Feichtinger K, Zapf C, Sings HL, Goodman M (1998a) Diprotected triflylguanidines: a new class of guanidinylation reagents. J Org Chem 63:3804-3805

Feichtinger K, Sings HL, Baker TJ, Matthews K, Goodman M (1998b) Triurethane-protected guanidines and triflyldiurethane-protected guanidines: new reagents for guanidinylation reactions. J Org Chem 63:8432-8439

Hau VS, Huber JD, Campos CR, Lipkowski AW (2002) Effect of guanidino modification and proline substitution on the in vitro stability and blood-brain barrier permeability of endomorphin II. J Pharm Sci 91:2140-2149

Heys L, Moore CG, Murphy PJ (2000) The guanidine metabolites of Ptilocaulisspiculifer and related compounds; isolation and synthesis. Chem Soc Rev 29:57-67

Jaeger S, Duran-Frigola M, Aloy P (2015) Drug sensitivity in cancer cell lines is not tissue-specific. Mol Cancer 14(1):40

Králová J, Dvorák M, Král V (2003) Novel cationic transport agents for oligonucleotide delivery into primary leukemic cells. J Med Chem 46:2049-2056

Liu HM, Liu XF, Yao JL, Wang CL (2006) Utilization of combined chemical modifications to enhance the blood-brain barrier permeability and pharmacological activity of endomorphin-1. J Pharmacol Exp Ther 319:308-316

Magri A, Reilly R, Scalacci N, Radi M, Hunter M, Ripoll M, Patel AH, Castagnolo D (2015) Rethinking the old antiviral drug moroxydine: discovery of novel analogs as anti-hepatitis $\mathrm{C}$ virus (HCV) agents. Bioorg Med Chem Lett 25:5372-5376

Massimba-Dibama H, Mourer M, Constant P, Daffé M, Regnouf-deVains JB (2015) Guanidinium compounds with sub-micromolar activities against Mycobacterium tuberculosis. Synthesis, characterization and biological evaluations. Bioorg Med Chem 23:5410-5418

Orner BP, Hamilton AD (2001) The guanidinium group in molecular recognition: design and synthetic approaches. J Incl Phenom 41:141-147

Pantos A, Tsogas I, Paleos CM (2008) Guanidinium group: a versatile moiety inducing transport and multicompartmentalization in complementary membranes. Biochim Biophys Acta 1778:811-823

Sidoryk K, Świtalska M, Jaromin A, Cmoch P, Bujak I, Kaczmarska M, Wietrzyk J, Dominguez EG, Żarnowski R, Andes DR, Bańkowski K, Cybulski M, Kaczmarek $€$ (2015) The synthesis of indolo[2,3-b]quinoline derivatives with a guanidine group: highly selective cytotoxic agents. Eur J Med Chem 105:208-219

Snider BB, Shi Z (1994) Biomimetic synthesis of the pentacyclic nucleus of ptilomycalin A. J Am Chem Soc 116:549-557

Yamamoto Y, Kojima S, Patai S, Rappoport Z (1991) Amidines and imidates. Wiley, Hoboken

Yuan C, Williams RM (1997) Total synthesis of the anti methicillinresistant Staphylococcus aureus peptide antibiotics TAN-1057AD. J Am Chem Soc 119:11777-11784 